\title{
Expert System of Chili Plant Disease Diagnosis using Forward Chaining Method on Android
}

\author{
Aristoteles \\ Computer Science, Mathematics and Natural Science \\ Faculty \\ Lampung University \\ Lampung, Indonesia \\ Mita Fuljana \\ Computer Science, Mathematics and Natural Science \\ Faculty \\ Lampung University \\ Lampung, Indonesia
}

\author{
Joko Prasetyo \\ Agriculture Faculty \\ Lampung University \\ Lampung, Indonesia
}

\begin{abstract}
This research was conducted to make an expert system that is able to diagnose disease in chili plants based on knowledge that provided directly from the experts. This research uses classical probability calculation method in calculating the percentage of diagnoses and implemented on the Android mobile device. This research consisted of 37 symptoms data, 10 data of chili disease caused by fungi, and 10 rules. This expert system uses forward chaining inference method. Test results shows: (1) Functional testing using the Black Box Equivalence Partitioning (EP) method give the results as expected on the test scenario on each test class. (2) Expert testing by comparing the results of manual and system calculations matches and run well. (3) User acceptance test is done to 53 respondents which is divided into four groups of respondents. The first respondents group that is consisting of experts of chili disease give average score of $\mathbf{8 5 . 1 4 \%}$ (excellent). The second group that consist of Agriculture Department students give score of $84.13 \%$ (excellent). The third respondent group that consist of Computer Science Department students give score of $\mathbf{8 4 . 2 8 \%}$ (excellent) whereas the last group (chili farmers) give a score of $86 \%$ (excellent).
\end{abstract}

Keywords-Android; classic probability; expert system; forward chaining; likert scale

\section{INTRODUCTION}

Chili is one of the important horticultural crops in Indonesia. Chili is classified as fruit and vegetable crops that have protein to be developed and have high economic value [1]. The production of chili during 2011-2013 tends to decrease [2]. The reduction of chili production is followed by high consumer needs. Fig. 1 is a graph of the development of chili production in Lampung province, Indonesia. At rainy season, the production of chili is reduced, while the demand is constant and continuous every day, even increase in certain seasons. One cause of decreased production is disease of chili plants.

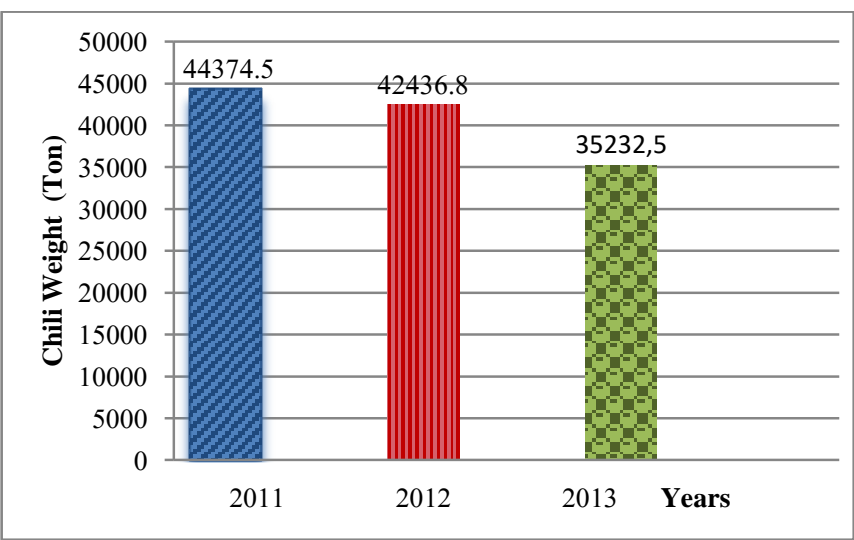

Fig. 1. Development of chili production of Lampung Province, 2011-13 [2].

The presence of disease attacks that attack chili plants can lead to crop failure. Therefore, the right control is needed to avoid that. The right control is not only when the attack is already happened, but the most important is the act of prevention. The late diagnosis process is caused by the lack of farmers' knowledge about the types of diseases that attack chili plants [3]. The diagnostic process needs an experienced expert in order to deliver the right conclusion. However, limited expert's available time become an obstacle for farmers to consult. In this case, expert system can be consulted as the second alternative in solving the problem. Based on the described explanation, the expert system that is able to diagnose chili plants disease is needed.

In this paper, we propose an expert system that can diagnose the chili plants disease. By developing the expert system, we hope the system can help farmers or field instructor in getting information about symptoms, chili disease and the way of handling the symptoms. 


\section{LITERATURE REVIEW}

\section{A. Chili}

Chili plant is one of the horticultural commodities that are categorized as season crops. Chili plants are estimated to be about 20 species that mostly grow in place of its origin, America. The classification of chili plants is as follows [4]:

$\begin{array}{ll}\text { Kingdom } & \text { : Plantae } \\ \text { Division } & \text { : Spermathophyta } \\ \text { Sub division } & \text { : Angiospermae } \\ \text { Class } & \text { : Dicotyledoneae } \\ \text { Subclass } & \text { : Metachlamydeae } \\ \text { Order } & \text { : Solanales } \\ \text { Family } & \text { : Solanaceae } \\ \text { Genus } & \text { : Capsicum } \\ \text { Species } & \text { : Capsicum annum } L .\end{array}$

B. Disease on Chili Plants

The chili disease caused by fungi is as follows [5]:

\section{1) Sprout Bee or Damping off}

Pathogen: One of Rhizoctonia solani, Pythium spp. Fusarium spp. Phytophthora sp. or Colletotrichum spp.

Symptoms: Chili seedlings fail to grow, seeds that have germinated die suddenly or dwarfed seedling because rootstock or root neck rot and dry. In the nursery place appear bald sprouts or chili pepper sporadically and spread irregularly.

\section{Prevention and control:}

a) Media for seeding using sub soil coating (1.5-2 m below ground level), fine mature manure and river sand in a ratio of $1: 1: 1$. This media mixture is pasteurized for 2 hours.

b) Infected seeds should be removed and destroyed, and the contaminated soil media should be disposed.

c) The nursery shade is gradually opened so the sunlight will reach the plants and the plants will become stronger. limits.

d) Use of selective fungicides with the lowest dose

\section{2) Anthracnose}

Pathogen: Colletotrichum spp.

Symptoms: Dead shoots that continue to the bottom. Leaves, twigs and branches dry rot blackish brown. On the trunk of acervuli the fungus is seen as a lump.

\section{Prevention and control:}

a) Balanced Fertilization, with Urea $150-200 \mathrm{~kg}$, ZA $450-500 \mathrm{~kg}$, TSP $100-150 \mathrm{~kg}, \mathrm{KCl} 100-150 \mathrm{~kg}$, and organic fertilizer 20-30 tons per hectare.

b) Chili intercropping in the highlands can reduce pest and disease attacks and increase yields.

c) The use of silver plastics mulch in the highlands, and straw in the lowland reduces Anthracnose infestation and soil diseases, especially in the rainy season.

d) Anthracnose disease caused by Colletotrichum spp. controlled with chlorotalonyl fungicide (Daconil ® 500 F, 2 g / 1) or Propineb (Antracol ® $70 \mathrm{WP}, 2 \mathrm{~g} / \mathrm{1}$ ). Both of these fungicides are used interchangeably. e) To reduce the use of pesticides $( \pm 30 \%)$, it is advisable to use fan nozzles that spray granules are mist and evenly distributed.

\section{Expert System}

Expert system is a system that seeks to adopt human knowledge to the computer, so that the computer can solve problems as usually done by experts. A good expert system is designed to solve a particular problem by imitating the work of the experts. With expert system, even common people can solve quite complex problems that can only be solved with the help of an expert. For experts, this expert system will also assist its activities as a highly experienced assistant [6].

The characteristics of expert systems are as follows:

1) Have a reliable information facility.

2) Easy to modify.

3) Can be used in various types of computers.

4) Have the ability to learn to adapt. [6]

Expert system consists of two main parts: the development environment and the consultation environment. The development environment is used as a builder both in terms of component and knowledge base. The consulting environment is used by the common people to consult. Expert system components can be seen in Fig. 2.

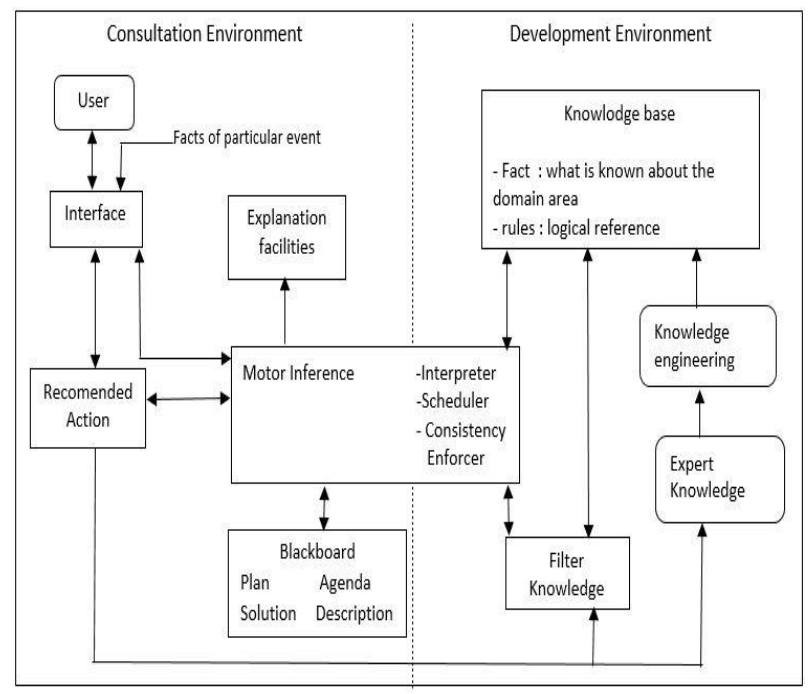

Fig. 2. Expert sytem structure [6].

\section{Classic Probability}

Probability is a quantitative way related to the existing uncertainty. Classic probability is also called a priori probability because it relates to a game or system. As mentioned earlier, the term a priori means "before" [7]. This probability is considered a kind of game, like throwing dice, card games, and tossing coins.

The general formula for classical probabilities is defined as the probability $P(A)$ with $\mathrm{n}$ is the number of occurrences, $n(A)$ represents the number of results getting $A$. Relative frequency the occurrence of $A$ is $\frac{n(A)}{n}$ then [7] : 


$$
P(A)=\frac{n(A)}{n}
$$

This classic probability is used to procure the probability of disease, so to calculate the percentage of illness is:

$$
\text { Percentage }(A)=P(A) \times 100 \%
$$

\section{MethodOLOGY}

\section{A. Research Stages}

The steps in this study are problem identification, problem formulation, data collection, system design, system development, and system testing. This research stage can be seen in Fig. 3.

\section{1) Problem Identification}

This stage is the process of formulating and limiting the problem to be studied. The formulation and limitation of the problem is needed in order to further lead the researcher in making the system so that the research done does not come out of the predetermined limits.

\section{2) Data Collections}

Data collection is done by using two methods, through literature reviews and interviews.

\section{a) Literature review}

At this stage data is collected through literature such as books, journals, or documents relating to research themes.

\section{b) Interview}

Interviewing experts aims to obtain data that could not be found in the literatures.

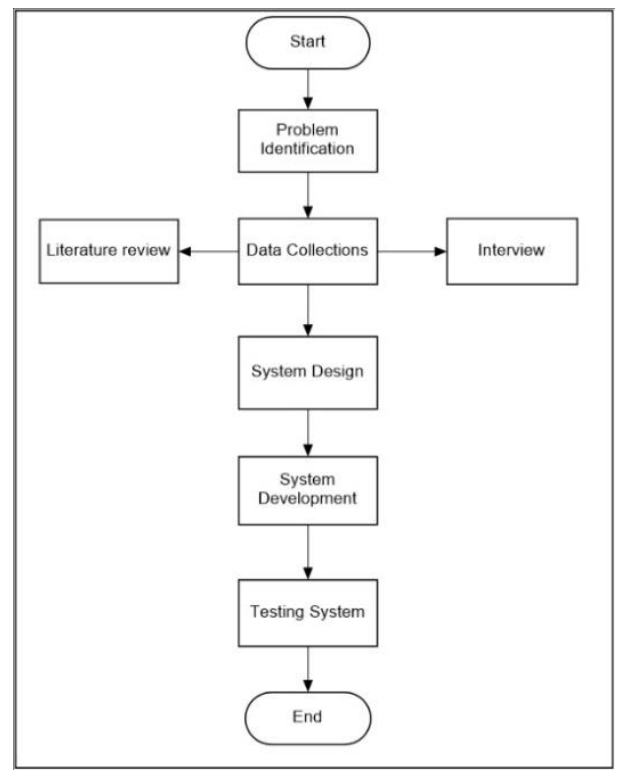

Fig. 3. Research stage.

\section{3) System Design}

System design is done by modeling the problem in the form of UML diagram (use case diagram). Design of use case diagram is presented in Fig. 4.

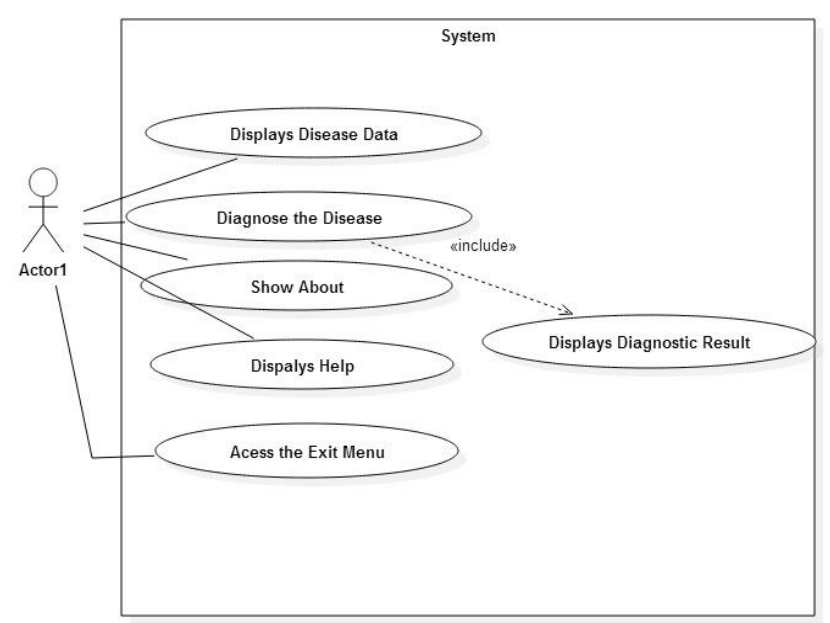

Fig. 4. Use Case diagram.

\section{B. Discussion}

1) Data Requirement Analysis

Data required on this expert system include symptom data and disease data on chili caused by fungi. Information on chili symptoms and diseases and their handling solutions come from consultation result with chili disease experts. It is found there are 37 types of symptoms and 10 types of chili disease caused by fungi. The list of symptoms and names of diseases in this expert system is coded " $G$ " for symptom data and " $P$ " for disease data.

\section{2) Percentage Analysis of Illness}

Percentage calculations in the expert systems are based on classical probability theory. This probability is used to procure opportunities for disease. For example, to calculate the percentage of diagnosis of Damping Off disease in Appendix 1 with four symptoms and one rule:

1. Chili seedlings fail to grow

2. Germinated seeds are dead

3. Dwarfs

\section{Symptoms of Sporadic}

The rule: "IF the Chili Seeds fail to grow AND the seeds are germinated dead AND The dwarfs and the symptoms in the sporadic seedbed THEN Damping Off."

Then the Calculation is:

If the user does consultation and provide the facts that the chili plant experiencing: 1) Chili paste failed to grow; 2) Germinated seeds are dead; 3) Little Pygmy; Then get $n=3$; $\mathrm{n}(\mathrm{A})=4 ; \mathrm{P}(\mathrm{A})=0.75$. Then the percentage of Damping Off is $75 \%$. So, based on the facts given the user can be concluded the diagnosis of Damping Off disease with the level of possible illness is $75 \%$ (almost sure).

3) Expert System of Diagnosis Chili Disease Application

The screenshots of expert system application of chili disease diagnosis implemented on android can be seen in Fig. 5, 6 and 7. 


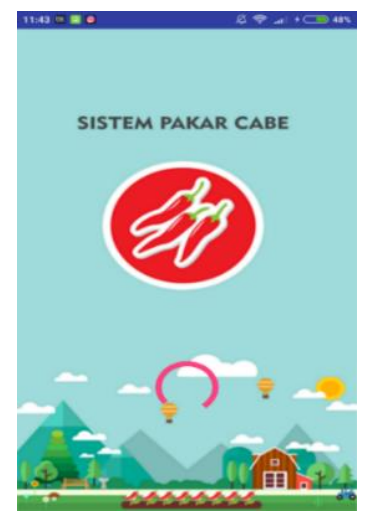

(a)

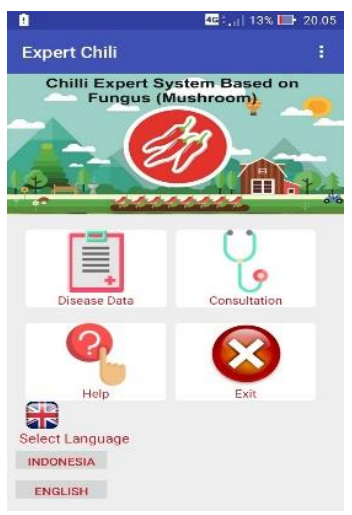

(b)
Fig. 5. (a) Spalsh screen, (b) Home page.

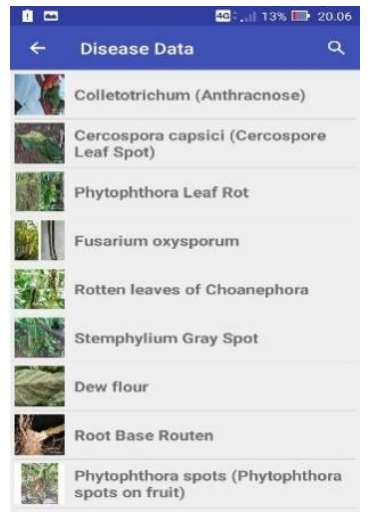

(a)

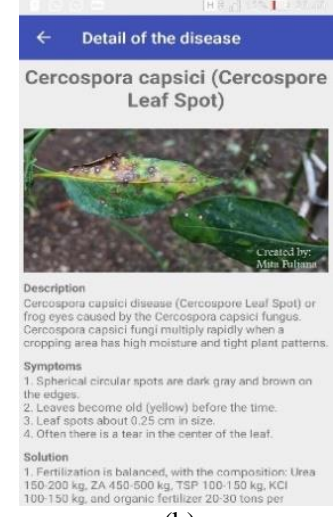

(b)
Fig. 6. (a) Disease data, (b) Disease detail.

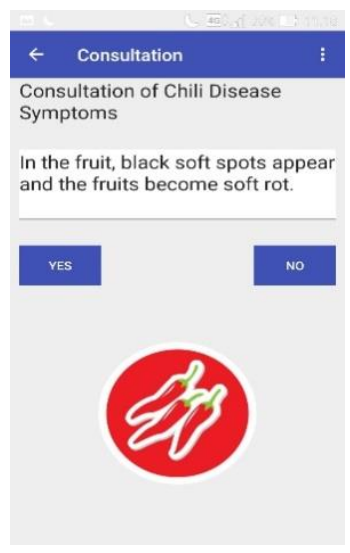

(a)

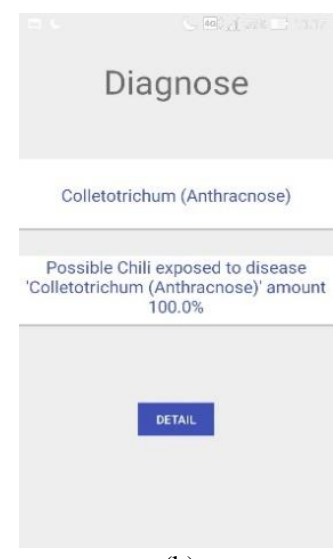

(b)
Fig. 7. (a) Symptom consultation, (b) Diagnostic results.

\section{4) Testing}

Testing of This expert system are cunducted in two tests: internal testing and external testing. Internal testing is done to test the functional of the system and test the expertise of the system based on the facts given.

\section{a) Functional testing}

Functional testing is used to find errors on the system that has been built. Functional testing in this study uses Black Box Equivalence Partitioning (EP) method. The functional testing process gets the expected results according to the test scenario in each test class.

\section{b) System expert testing}

Experimental test system aims to see the expert system's ability in the application in identifying the type of chili disease based on the facts of symptoms given. Testing was done with 12 cases.

\section{c) External testing}

External testing is done by collecting questionnaires filled by randomly selected respondents. This external test involved 53 respondents to get a direct assessment of the resulting system. These respondents were categorized into four categories with the aim of comparing the assessment results of chili disease respondents, who studied chili disease, who did not study at all about chili disease, and chili farmers. Categories of respondents in this study are as follows:

1) Category of Respondents I: Experts on chili diseases, with details of 5 lecturers' faculty majoring in Agriculture.

2) Category of Respondents II: People who learn about chili disease, which is 18 students of Agriculture Department.

3) Category of Respondents III: People who do not learn about chili disease, which is 20 students Computer Science Department.

4) Category of Respondents IV: People who grow chili are 10 farmers.

In this respondents are asked to access the application directly and provide an assessment of the application by filling out a questionnaire. Assessment categories consist of:

- Very Good (SB), with the value of 5.

- Good (B), with the value of 4 .

- Good enough (CB), with the value of 3 .

- Less Good (KB), with the value 2.

- $\quad$ Not Good (TB), with the value 1.

The formula for determining percentage of criterion-based valuations on the Likert Scale is to use the following mean arithmetic formulas [8]:

$$
P=\frac{X i}{n(N)}(100 \%)
$$

Description:

$P=$ Percentage of statements

$X i=$ Total qualitative value

$n=$ Number of respondents

$N=$ Value of the best statement category

To analyze the questionnaire results, criteria of the assessment index is needed to facilitate the interpretation of the conclusion of the questionnaire results. Criteria of the assessment index is categorized into five categories, which is very good, good, good enough, less good, and not good. The following is the calculation of index criteria: 


$$
\begin{gathered}
I=\frac{100 \%}{K} \\
I=\frac{100 \%}{5} \\
I=20 \%
\end{gathered}
$$

Based on the calculation of the above interval, obtained interval value is $20 \%$. Criteria index of respondents' assessment of the system is presented in Table 1.

Fig. 8 is a graph of the test results of the questionnaire.

TABLE I. CRITERIA ASSESMENT INDEX RESUlt QUESTIONNAIRE

\begin{tabular}{|l|l|}
\hline Answer & Description \\
\hline $0 \%-19.99 \%$ & Not Good \\
\hline $20 \%-39.99 \%$ & Less Good \\
\hline $40 \%-59.99 \%$ & Good Enough \\
\hline $60 \%-79.99 \%$ & Good \\
\hline $80 \%-100 \%$ & Very Good \\
\hline
\end{tabular}

Results of Questionnaire Testing

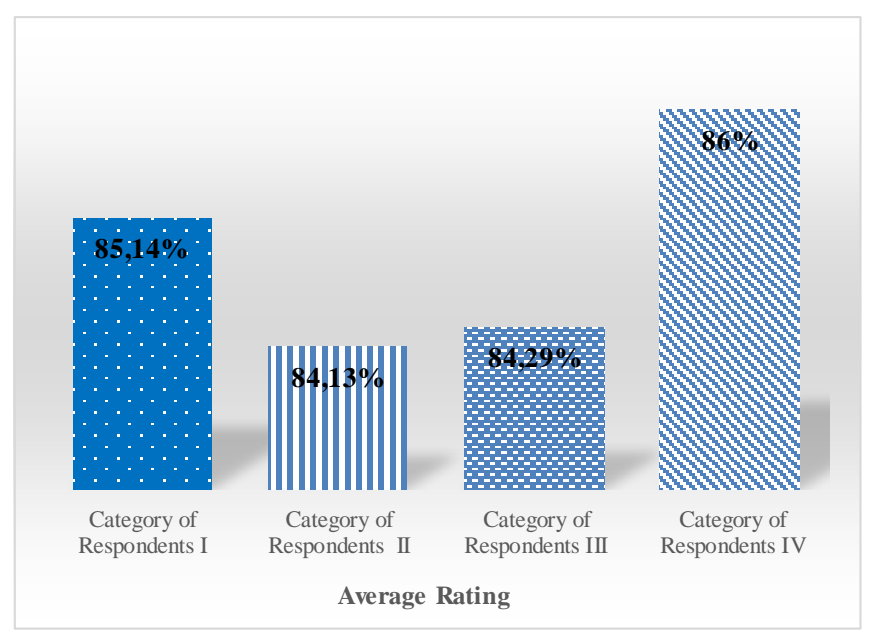

Fig. 8. Average values of questionnaire testing results.
Based on the questionnaire result, it can be concluded that the application "Expert Chili App" obtained an average percentage of appraisal of $85.14 \%$ (very good) according to respondent group I (the lecturer of agriculture), $84.13 \%$ (very good) according to respondent group II (student of agriculture), $84.28 \%$ (very good) according to respondent group III (student of computer science), and $86 \%$ (very good) according to respondent group IV (chili farmers).

\section{CONCLUSIONS}

Based on the results of research that has been done, it can be concluded that:

1) The application of "Chili Expert System" has been successfully developed to assist the general public and farmers in identifying diseases caused by fungi based on the symptoms given.

2) The built expert systems is useful for public and farmers to find out information about chili diseases.

3) The results of functional testing indicate that the expert system built has been running as expected.

4) Based on the assessment of the use of the application through the questionnaire, it can be concluded that "Expert Chili App" obtained "very good" - "excellent" result.

\section{REFERENCES}

[1] Ralahalu, M. S., Hehanusa, M. L., and Oszaer, L.L, "Respon Tanaman Cabai Besar (Capsicum annum L) Terhadap Pemberian Pupuk Organik Hormon Tanaman Ungul”, Jurnal Ilmu Budaya Tanaman, vol. 2, no. 2, Oktober 2013.

[2] Badan Pusat Statistik Lampung. 2014. Berita Resmi Statistik Provinsi Lampung.Lampung: Badan Pusat Statistik Provinsi Lampung.

[3] Muslim, 2015. Sistem Pakar Diagnosa Hama Dan Penyakit Cabai Berbasis Teorema Bayes. Vol. 4, No. 3, Desember 2015 : 797 - 876.

[4] Pitojo, S., 2003. Benih Cabai. Yogyakarta :Kanisius.

[5] Duriat, A. S., Gunaeni, N., and Wulandari, A. W. 2007. Penyakit Penting Tanaman Cabai dan Pengendaliannya. Monografi, 1 (31).

[6] Kusumadewi, Sri. 2003. Artificial Intelligence: Teknik dan Aplikasinya. Edisi 1. Yogyakarta: Graha Ilmu.

[7] Arhami,M. 2005. Konsep Dasar Sistem Pakar. Yogyakarta: Andi.

[8] Aristoteles, Wardianto, and Ardye Amando Pratama, "Sistem Pakar Diagnosa Penyakit pada Ikan Budidaya Air Tawar dengan Metode Forward Chaining,” Jurnal Komputasi, vol. 3, no. 2, pp. 92-98, 2015. 